\title{
Speciation in Macropsinae leafhoppers (Homoptera: Auchenorrhyncha: Cicadellidae) - the role of acoustic signal divergence and host plant shifts
}

\author{
Видообразование у џикадок подсемейства Масторsinae \\ (Homoptera: Auchenorrhyncha: Cicadellidae): роль различий \\ в структуре акустических сигналов \\ и перехода на новые кормовые растения
}

\section{D.Yu. Tishechkin \\ A.Ю. Тишечкин}

Department of Entomology, Faculty of Biology, M.V. Lomonosov Moscow State University, Vorobyevy Gory, Moscow 119991, Russia. Email: macropsis@yandex.ru

Кафедра энтомологии Биологического факультета Московского государственного университета имени М.В. Ломоносова, Воробьевы Горы, Москва 119991, Россия.

KEY WORDS: leafhoppers, Homoptera, Auchenorrhyncha, Cicadellidae, Macropsinae, speciation, divergence, vibrational signals, host shift, specific mate recognition system.

КЛЮЧЕВЫЕ СЛОВА: цикадки, Ноmoptera, Auchenorrhyncha, Cicadellidae, Macropsinae, видообразование, дивергенция, вибрационные сигналы, кормовые растения.

ABSTRACT. Examples of divergence in various traits in allopatric, formally sympatric (dwelling on the same territory, but on different hosts), and strictly sympatric (dwelling on the same territory and host) species of Macropsinae are considered. Strictly sympatric species always differ from each other in calling signal pattern. Formally sympatric and allopatric species can produce similar signals, because partitioning of acoustic transmission channels in this case is provided by ecological or geographical isolation. The divergence in coloration and/or morphology is a secondary event in relation to signal divergence or range disjunction. Different traits can diverge independently of one another; as a result, some species differ in coloration, but not in genitalia shape, the others differ in genitalia shape, but not in coloration. Thus, this is the calling signal pattern, but not coloration or genitalia shape, which is a key element of specific mate recognition system in small Auchenorrhyncha. Host shift and geographic isolation of populations from the same host apparently are two main speciation modes in leafhoppers. Different modes can be realized in different species groups even within the same subfamily or genus.

РЕЗЮМЕ. Рассмотрены примеры дивергенции по разным группам признаков у аллопатрических, нестрого симпатрических (обитающих на одной территории, но на разных кормовых растениях) и строго симпатрических (живущих на одной территории и на одном кормовом растении) видов Macropsinae. Строго симпатрические виды всегда различаются по структуре призывных сигналов. Нестрого симпатрические и аллопатрические виды могут издавать сходные сигналы, т.к. у них разделение каналов акустической коммуникации происходит за счёт экологической или географической изоляции. Различия в окраске и/или строении гениталий формируются уже после возникновения географических или акустических барьеров, причём дивергенция по разным группам признаков может происходить независимо. В результате, в одних случаях внешне сходные виды различаются по морфологии гениталий, в других - виды, неразличимые по форме гениталий, различаются по окраске. Таким образом, именно паттерн призывных сигналов, а не окраска или строение гениталий является у мелких цикадовых ключевым элементом системы распознавания конспецифического полового партнёра. Переход на новые кормовые растения и географическая изоляция популяций, связанных с одним видом растений, по-видимому, представляют собой у цикадовых два основных механизма видообразования. Оба они могут реализовываться в разных группах близких видов даже в пределах одного рода или подсемейства.

\section{Introduction}

Reproductive isolation between biological species is maintained due to specific mate recognition systems (SMRS) which allow to discriminate between con- and 
heterospecific individual, and thus to avoid heterospecific mating. The more effective SMRS, the more strong reproductive isolation between the species under consideration.

In insects using intraspecific acoustic communication, SMRS necessarily include calling (= mating) signals. For example, calling signals in sympatric species are always different, therefore each species occupying its own communication channel or so-called "acoustic niche" [Riede, 1996; Sueur, 2002; Tishechkin, 2011a; Tishechkin \& Bukhvalova, 2010]. Also, it is common knowledge that cryptic species indistinguishable in morphology usually differ from each other in signal patterns [e.g. Tishechkin, 2003, 2005, 2013]. Therefore, calling signals are the major components of SMRS. On this basis one could conclude that these are the differences in signal pattern, which appear at the first stage of population divergence and establish a starting point for speciation.

Investigation of closely related species shows that this is not always the case, however. Not only the songs become different during speciation, but also the genitalia, since both are the parts of SMRS.

For instance, among bushcrickets (Orthoptera: Tettigoniidae) there are many examples of species differing in song, but not in genitalia morphology. On the other hand, species differing in genitalia morphology, but not in song are known as well. Thus, there are no strict rules about what changes first at the initial stage of speciation. Moreover, in most studied cases differences in song pattern seem to appear more slowly than changes in morphology [Heller, 2006].

Many insects produce not air-borne, but vibrational signals transmitted via solid substrate. Among them are small Auchenorrhyncha, Psyllinea, and Aleyrodinea (Homoptera), certain Heteroptera (Coreidae, Pentatomomorpha, etc.), and a number of other herbivorous forms [Drosopoulos, Claridge, 2006]. Vibrations cannot be transmitted from one plant to another without physical contact between them. Within the same community vibrational signals can, in certain situations, travel from plant to plant both via touching stems or leaves and via the roots [Tishechkin, 2011b]. However, if two host species grow in different plant communities, insects dwelling on these plants cannot perceive the signals of each other, i.e. are acoustically isolated.

That is why it is widely accepted that in insect herbivores, as well as in other specialist feeders, this is a host shift, which triggers speciation in many cases. American treehoppers from Enchenopa binotata Say, 1824 species complex (Homoptera: Auchenorrhyncha: Membracidae) presently are the best-documented example of sympatric speciation in Auchenorrhyncha. In this group shifting to host plants with different phenologies resulted in changes of life-history timing including mating period. This mistiming reduced gene flow between populations on ancestral and novel plants.

In addition, every stem or twig acts as a complex frequency filter that attenuates insect vibrational songs.
Different plant species differ from each other in signal transmission properties i.e. frequency responses. For this reason natural selection resulted in signal frequency change so as to minimize attenuation in plant stems. Differences in signal frequency between populations initially developed as an adaptation to physical properties of their respective hosts provide additional reproductive isolation barrier [Rodríguez et al., 2004; McNett \& Cocroft, 2008].

It is evident that divergence via host shift in Auchenorrhyncha is not the only way of speciation [Claridge, 1993; Drosopoulos, 1993]. In the opinion of Claridge \& de Vrijer [1994], despite all arguments for sympatric speciation of many herbivorous insects along host plant lines, the evidence is not strong for Auchenorrhyncha.

First, host differences by no means always provide partitioning of vibratory transmission channels [Tishechkin, 2011b].

Second, specific filtering properties of a host plant can affect signal frequency, but not temporal pattern (phrase duration, syllable pattern and repetition period, etc.). However, signals of cryptic species for the most part differ in temporal pattern, but not in the main frequency [Tishechkin, 2003, 2009, 2013]. Moreover, in certain cases closely related species dwelling on the same host produce signals with different main frequencies; Gargara genistae (Fabricius, 1775) and G. mongolica Dlabola, 1965 (Membracidae) can be mentioned as an example [Tishechkin \& Burlak, 2013]

Third, there are many examples of congeneric species differing in signal pattern, but dwelling on the same host. These are planthoppers from the genus Chloriona Fieber, 1866 (Delphacidae) feeding on the common reed (Phragmites australis (Cav.) Trin. ex Steud.) [Gillham \& de Vrijer, 1995], three closely related species of Laburrus Ribaut, 1942 (Cicadellidae: Deltocephalinae) dwelling on wormwood (Artemisia spp.) [Tishechkin, 2009], numerous species from the genus Paralimnus Matsumura, 1902 (Cicadellidae: Deltocephalinae), all dwelling on the common reed, and many others. As a consequence in insect herbivores differences in signal pattern can evolve without host shift, but this is possible only in the course of allopatric speciation. Also, in allopatric species divergence in genitalia shape without signal divergence is possible.

The aim of the present paper is to demonstrate that even within the same subfamily or genus divergence in various traits can occur in different groups of closely related species.

Leafhoppers from the subfamily Macropsinae (Homoptera: Auchenorrhyncha: Cicadellidae) provide the most prominent example of such a taxon. Certain genera of Macropsinae (Macropsis Lewis, 1836, Oncopsis Burmeister, 1838, Macropsidius Ribaut, 1952) comprise large groups of closely related cryptic species hardly if at all distinguishable in morphological traits. Most representatives of the subfamily are mono- or oligophagous forms. In addition, male vibrational calling signals are described for the most part of Palaearctic species [Tishechkin, 1999, 2002, 2006]. 


\section{Material and methods}

Vibrational signals were registered by means of piezo-electric crystal gramophone cartridge GZP-311 connected to the microphone input of a cassette recorder "Elektronika-302-1" or (since 2005) minidisk recorder Sony Walkman MZ-NH900 via the custom-

made matching amplifier. Recordings were made under laboratory or field conditions immediately after collecting the insects.

Data on insect collecting sites are given in the Table 1. The specimens investigated are deposited in the collection of the Zoological Museum of M.V. Lomonosov Moscow State University.

Table 1. Data for signal recordings used in the paper. Таблица 1. Данные об использованных в статье записях сигналов.

\begin{tabular}{|l|l|}
\hline \multicolumn{1}{|c|}{ Species } & \multicolumn{1}{c}{ Locality } \\
\hline Macropsidius sahlbergi (F1.) & $\begin{array}{l}\text { Saratov Area, Krasnokutskiy Region, env. Dyakovka Vill., Artemisia arenaria } \\
\text { in sand steppe. }\end{array}$ \\
\hline M. chazarianus Logv. & $\begin{array}{l}\text { Dosang Railway Station ca. 60 km North of Astrakhan', A. arenaria in sand } \\
\text { desert. }\end{array}$ \\
\hline Macropsis impura (Boh.) & $\begin{array}{l}\text { Kyrgyzstan, Inner Tien Shan Mts., Dzhumgal Riv. Valley between Baizak and } \\
\text { Chaek, Salix rosmarinifolia in the bog near the spring. }\end{array}$ \\
\hline M. flavida Vilb. & $\begin{array}{l}\text { 1. Southern Maritime Province, Khasan Region, Ryazanovka Vill., Salix sp. } \\
\text { 2. Amur Area, Kostyukovka Vill. 30 km West of Svobodny Town, S. udensis. }\end{array}$ \\
\hline M. multa Tish. & $\begin{array}{l}\text { Amur Area, Kostyukovka Vill. 30 km West of Svobodny Town, S. } \\
\text { brachypoda. }\end{array}$ \\
\hline M. daurica Tish. & Amur Area, Zeya Riv. ca. 15 km North of Blagoveshchensk, S. nipponica. \\
\hline M. ochotonaria Tish. & Chita Area, Ingoda Riv. 15 km East of Urul'ga Vill., S. miyabeana. \\
\hline M. leporina Tish. & Same locality, S. schwerinii. \\
\hline M. mulsanti (Fieb.) & $\begin{array}{l}\text { Kyrgyzstan, Chatkal Mtn. Range, Sary-Cheleksky Nature Reserve, Arkyt } \\
\text { Vill., Hippophae rhamnoides on the bank of Khodzha-Ata Riv. }\end{array}$ \\
\hline M. pictipes (Horv.) & Same locality and host. \\
\hline M. emeljanovi Dub. & Same locality and host. \\
\hline M. elaeagni Em. & $\begin{array}{l}\text { Kyrgyzstan, West Tien Shan Mts., foothills of Chatkal Mtn. Range, env. } \\
\text { Karajigach Vill., Elaeagnus sp. }\end{array}$ \\
\hline M. elaeagnicola Dub. & $\begin{array}{l}\text { Kyrgyzstan, West Tien Shan Mts., foothills of Chatkal Mtn. Range, env. Ak- } \\
\text { Jol Vill., Elaeagnus sp. }\end{array}$ \\
\hline
\end{tabular}

\section{Results}

In the present item examples of divergence in various traits in (a) allopatric, (b) formally sympatric i.e. inhabiting the same territory, but dwelling on different hosts, and (c) strictly sympatric (dwelling on the same territory and host) species of Macropsis and Macropsidius are considered. Data on similarity/differences in distribution, host preferences, morphology, coloration, and signals within each species group are summarised in Table 2.

Table 2. Differences in various traits within the groups of closely related species of Macropsinae. Таблица 2. Различия по разным группам признаков у близких видов Macropsinae.

\begin{tabular}{|l|c|c|c|c|c|}
\hline \multicolumn{1}{|c|}{ Species } & Distribution & Signals & Hosts & Coloration & Genitalia \\
\hline $\begin{array}{l}\text { Macropsidius sahlbergi (Fl.) } \\
\text { and M. chazarianus Logv. }\end{array}$ & Allopatric & Similar & $\begin{array}{c}\text { Partially } \\
\text { same }\end{array}$ & Similar & Different \\
\hline $\begin{array}{l}\text { Macropsis impura (Boh.) } \\
\text { and M. flavida Vilb. }\end{array}$ & Allopatric & $\begin{array}{c}\text { Share common } \\
\text { elements }\end{array}$ & Different & $\begin{array}{c}\text { Similar in certain } \\
\text { colour variations }\end{array}$ & Similar \\
\hline $\begin{array}{l}\text { M. daurica Tish., M. multa } \\
\text { Tish., and } M \text {. flavida Vilb. }\end{array}$ & $\begin{array}{c}\text { Formally } \\
\text { sympatric }\end{array}$ & $\begin{array}{c}\text { Share common } \\
\text { elements }\end{array}$ & Different & $\begin{array}{c}\text { Similar in certain } \\
\text { colour variations }\end{array}$ & Similar \\
\hline $\begin{array}{l}\text { M. ochotonaria Tish. and M. } \\
\text { leporina } \text { Tish. }\end{array}$ & $\begin{array}{c}\text { Formally } \\
\text { sympatric }\end{array}$ & $\begin{array}{c}\text { Share common } \\
\text { elements }\end{array}$ & Different & Similar & Similar \\
\hline $\begin{array}{l}\text { M. mulsanti } \text { (Fieb.), M. pictipes } \\
\text { (Horv.), and M. emeljanovi } \\
\text { Dub. }\end{array}$ & $\begin{array}{c}\text { Strictly } \\
\text { sympatric }\end{array}$ & Different & Same & Different & Similar \\
\hline $\begin{array}{l}\text { M. elaeagni Em. and M. } \\
\text { elaeagnicola } \text { Dub. }\end{array}$ & $\begin{array}{c}\text { Strictly } \\
\text { sympatric }\end{array}$ & Different & Same & Similar & Different \\
\hline
\end{tabular}


1. Macropsidius sahlbergi (Flor, 1861) and M. chazarianus Logvinenko, 1981:

allopatric species different in morphological traits, but indistinguishable in signal pattern.

M. sahlbergi and M. chazarianus dwell on the wormwoods (Artemisia) from the subgenus Dracunculus. I have collected the former species from Artemisia campestris L. in Moscow Area and from A. arenaria DC. in Saratov Area, whereas the latter one was found on $A$. arenaria and $A$. scoparia Waldst. et Kit. ca. $60 \mathrm{~km}$ North of Astrakhan'. Thus they have at least one common host species. The range of $M$. sahlbergi includes the most part of Europe, Southern regions of West Siberia, and the steppes of Kazakhstan; also it was found in two localities in Kyrgyzstan. M. chazarianus apparently is endemic of sand deserts of the Northern part of Caspian Depression [Tishechkin, 2006]. Both species were never found in the same locality so they can be regarded as allopatric.

These species are quite similar to each other in external appearance, but differ distinctly in penis shape (Figs 1-2 and 3-4).

Calling signals of $M$. sahlbergi and $M$. chazarianus are indistinguishable in temporal pattern (Figs 5, 7 and $6,8-9)$, but evidently they do not suffer acoustic interference due to allopatry. It must be emphasized here, that leafhopper signals are quite variable, so some minor differences in phrase duration (Figs 7-9) and amplitude relation of their different components are not species-specific traits [Tishechkin, 2010].

\section{Macropsis impura (Boheman, 1847) and} M. flavida Vilbaste, 1980:

allopatric species indistinguishable in morphological traits and similar in signal pattern.

M. impura and M. flavida represent another pair of allopatric closely related species. The range of the former one includes Europe, West Siberia eastwards as far as Altai Mts., Kazakhstan, and Kyrgyzstan. The latter one was found in Central Siberia (Tyva), Irkutsk Area, Transbaikalia, the Russian Far East, and China (Qinghai). In other words, these two species inhabit Western and Eastern parts of Palaearctic, respectively. M. impura is monophagous on Salix repens L. and $S$. rosmarinifolia (L.) Celak, $M$. flavida dwells on many willow species, but was never found on $S$. repens and $S$. rosmarinifolia so far.

In contrast to two Macropsidius species, M. impura and $M$. flavida are indistinguishable in the shape of male genitalia. Moreover, both species have many colour forms and their colour variation ranges overlap considerably. For this reason quite often they are similar also in coloration i.e. provide an example of typical cryptic species.

Calling signals of both species are prolonged complex phrases lasting from 5-6 up to ca. 20 s (Figs 10-11 and 12-13). Signals vary greatly in temporal patterns (i.e. duration and amplitude relation of signal elements) and share common elements (Figs 14-17). Therefore these two species sometimes are almost indistinguishable in signal pattern as well.
3. Macropsis flavida, M. daurica Tishetshkin, 1997 and M. multa Tishetshkin, 1997:

formally sympatric species similar both in morphological traits and signal pattern.

Macropsis flavida, M. daurica, and M. multa are East-Palaearctic willow-dwelling species with the ranges overlapping in Eastern Transbaikalia and Amur Area. For instance, I have found all the three ones in the same locality in the valley of Zeya River, Amur Area. These species are not strictly sympatric, since their hosts have different ecological preferences. The host plant of $M$. daurica, Salix nipponica Franch. et Savat., grows in wide river valleys, mainly on sand soils. M. multa dwells on $S$. brachypoda (Trautv. et Mey.) Kom. growing in wet meadows and in the bogs. Occasionally it can be found on other willow species outside its typical habitats; e.g. once I have collected one male on the bank of Zeya River from S. schwerinii E.Wolf. M. flavida dwells on various willows, but I have never found it in large river valleys in Chita and Amur Areas, where $M$. daurica was found; it rather prefers willow thickets along small forest rivers and brooks.

These species are similar in morphological traits [Tishechkin, 1999], but partially differ in coloration. $M$. daurica is always green (Fig. 20), M. multa has green (dominant) and brown (rather rare) variations (Figs 2122), whereas M. flavida has only brown and reddishbrown colour forms (Figs 18-19). Calling signals of all the three species are prolonged single or repeated phrases lasting from ca. 7-8 up to 15-20 s and more (Figs 2325 ). Signals of different species share common elements (Figs. 26-28), still they retain species-specific differences.

\section{Macropsis ochotonaria Tishetshkin, 1994 and} M. leporina Tishetshkin, 1997:

formally sympatric species indistinguishable in morphological traits, but different in signal pattern.

M. ochotonaria and M. leporina are willow-dwelling species with partially overlapping ranges. The former species occurs from Tyva (West Siberia) to Amur Area (Zeya River Valley), the latter one - from Transbaikalia to the Pacific Coast of the Russian Far East. M. ochotonaria lives on Salix spp. from the section Helix (S. ledebouriana Trautv. in Tyva, S. miyabeana Seemen in East Siberia), whereas M. leporina - on Salix spp. from the section Vimen ( $S$. schwerinii E. Wolf, S. udensis Trautv. et Mey.). In Transbaikalia I have found both species in the same biotope quite often, because their hosts in these parts ( $S$. miyabeana and $S$. schwerinii) usually form mixed thickets on riverbanks. Under such conditions vibration transmission from one plant to another via the twigs that interlace is quite possible. Therefore these two species apparently can perceive the signals of each other.

$M$. leporina and M. ochotonaria are cryptic species indistinguishable both in morphology and coloration [Tishechkin, 1999]. Their signals differ distinctly in temporal pattern (Figs 29, 32 and 30-31, 33), but share one similar component, a succession of high-amplitude 

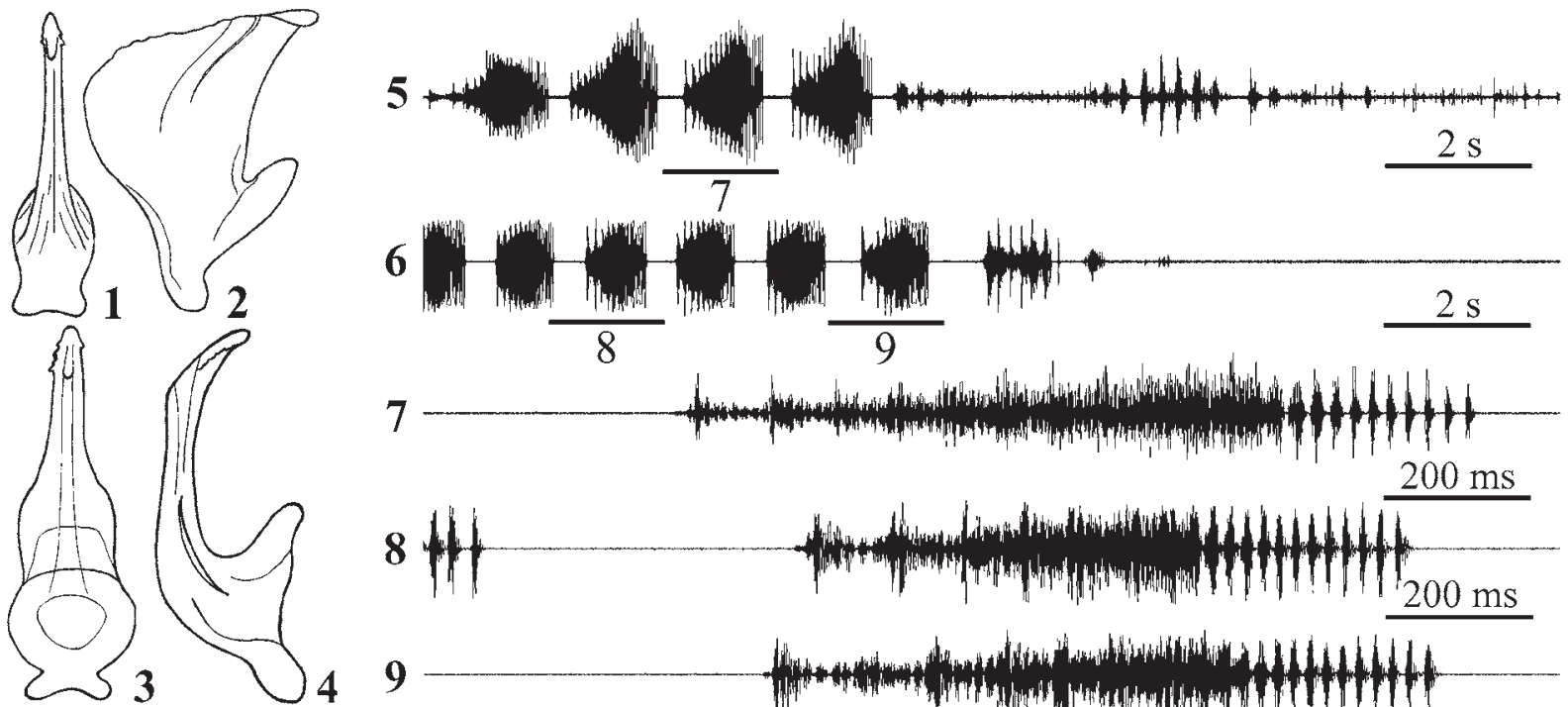

6

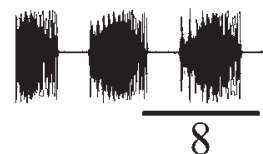

7

7

8 H

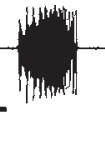

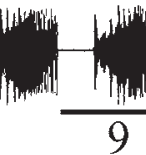

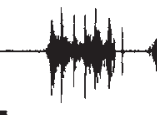

$2 \mathrm{~s}$

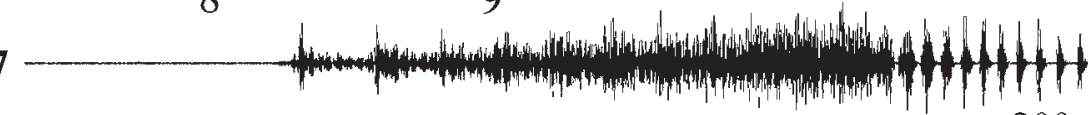

$200 \mathrm{~ms}$

9

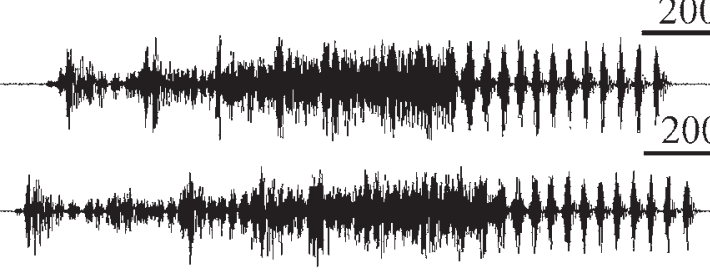

$200 \mathrm{~ms}$

10
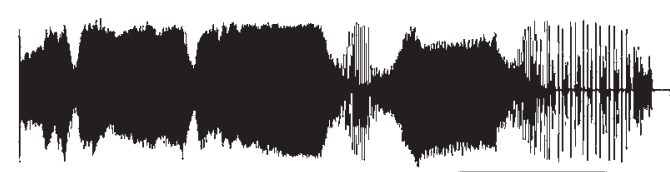

$+4$

(h)
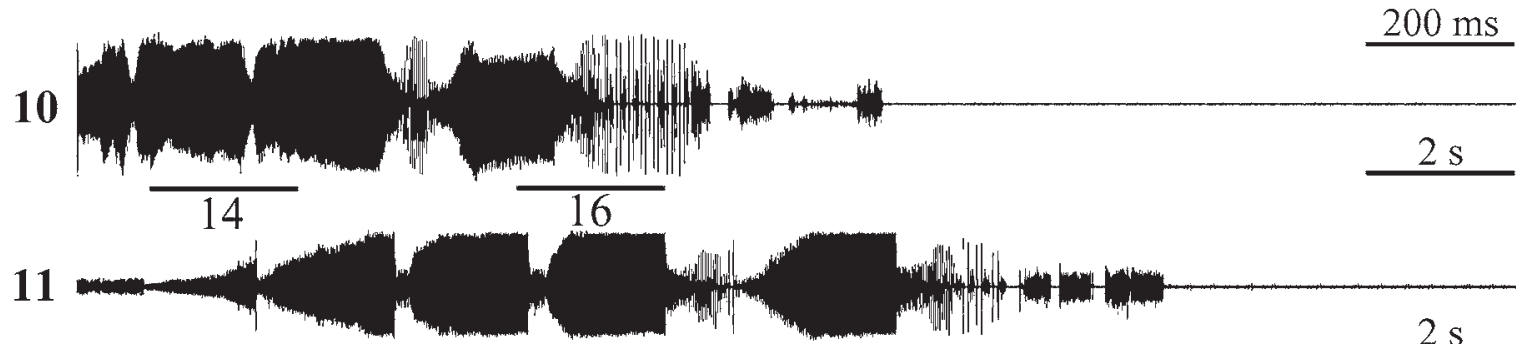

Him.n.m.

12

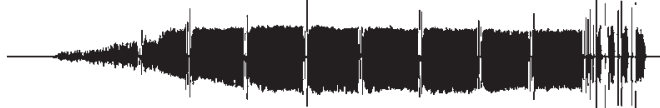

13

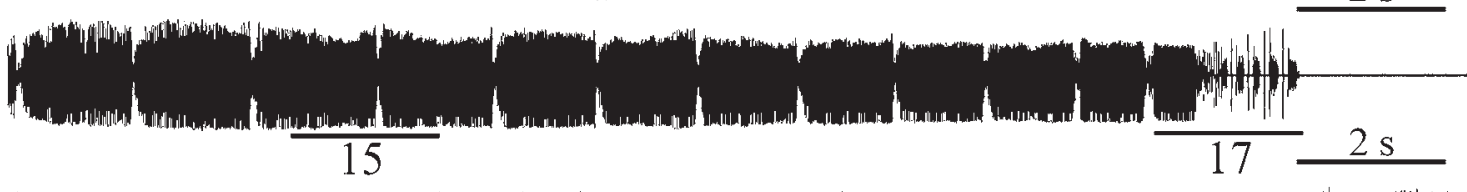

14

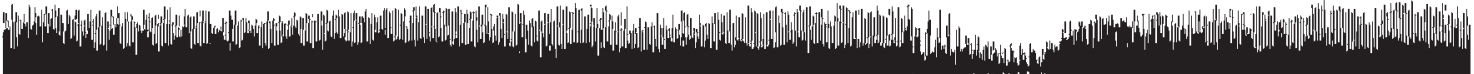

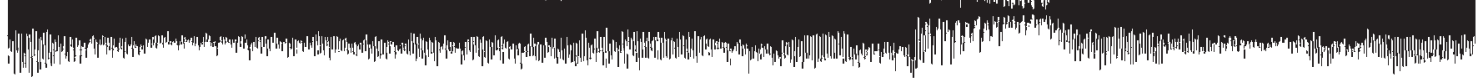

$200 \mathrm{~ms}$

15

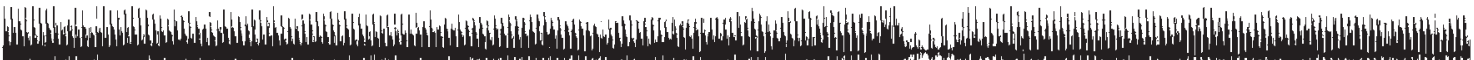

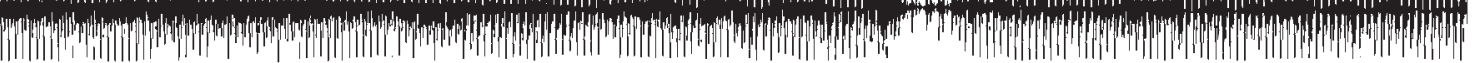

16

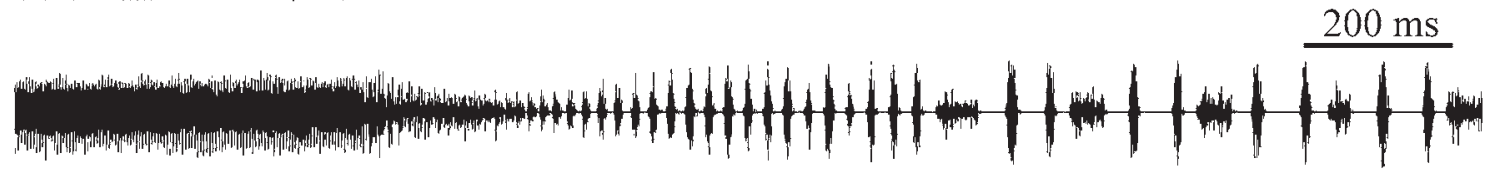

17

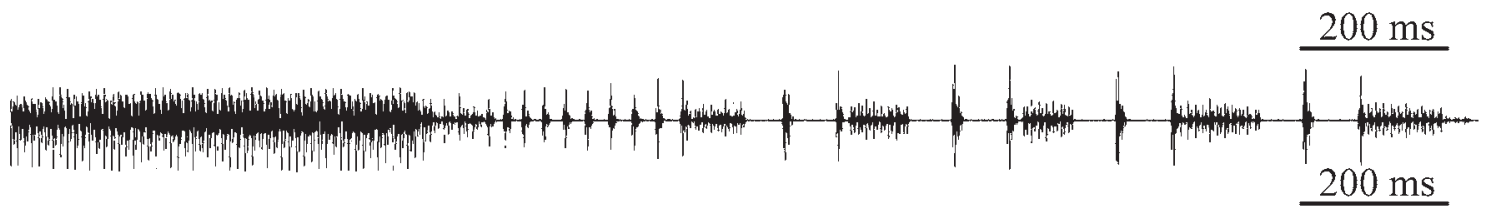

Figs 1-17. Macropsidius sahlbergi - 1-2, 5, 7; M. chazarianus - 3-4, 6, 8-9; Macropsis impura - 10-11, 14, 16; M. flavida - 12$13,15,17 ; 1-4$ - penis (1, 3- back view; 2, 4 - lateral view); 5-17 - oscillograms of male calling signals. Faster oscillograms of the parts of signals indicated as "7-9" and "14-17" are given under the same numbers.

Рис. 1-17. Macropsidius sahlbergi - 1-2, 5, 7; M. chazarianus - 3-4, 6, 8-9; Macropsis impura - 10-11, 14, 16; M. flavida - 12$13,15,17 ; 1-4$ - пенис (1, 3 - сзади; 2, 4 - сбоку); 5-17- осциллограммы призывных сигналов самцов. Фрагменты сигналов, помеченные цифрами “7-9” и “14-17”, представлены при большей скорости развёртки на осциллограммах под такими же номерами. 


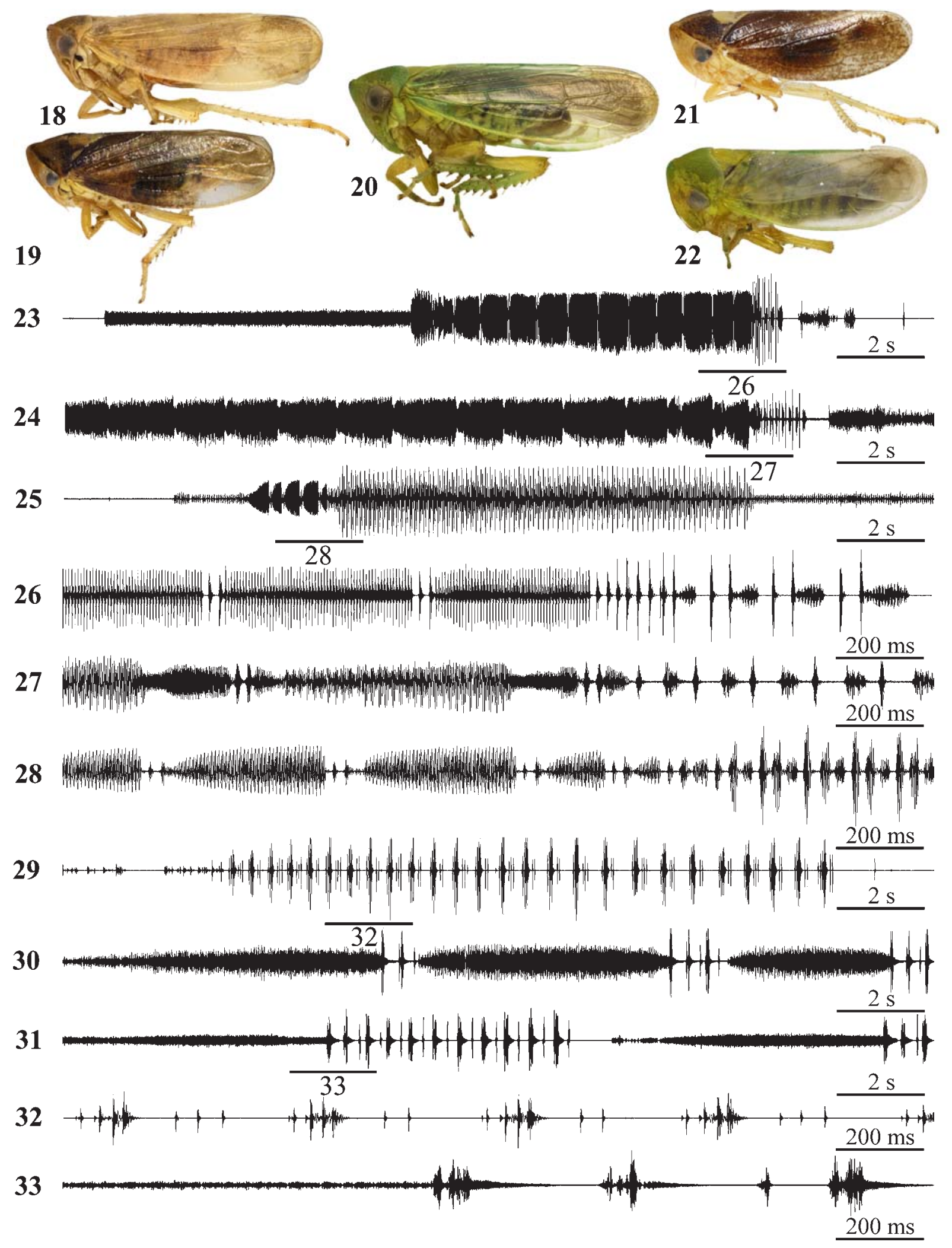

Figs 18-33. Macropsis spp.: M. flavida - 18-19, 23, 26; M. daurica - 20, 24, 27; M. multa - 21-22, 25, 28; M. leporina - 29, 32; M. ochotonaria - 30-31, 33; 18-22 - general view of a body, lateral aspect; $23-33$ - oscillograms of calling signals. Faster oscillograms of the parts of signals indicated as "26-28" and "32-33" are given under the same numbers.

Рис. 18-33. Macropsis spp.: M. flavida - 18-19, 23, 26; M. daurica - 20, 24, 27; M. multa -21-22, 25, 28; M. leporina - 29, 32; M. ochotonaria - 30-31, 33; 18-22 - общий вид сбоку; 23-33 - осциллограммы призывных сигналов самцов. Фрагменты сигналов, помеченные цифрами “26-28” и “32-33”, представлены при большей скорости развёртки на осциллограммах под такими же номерами. 

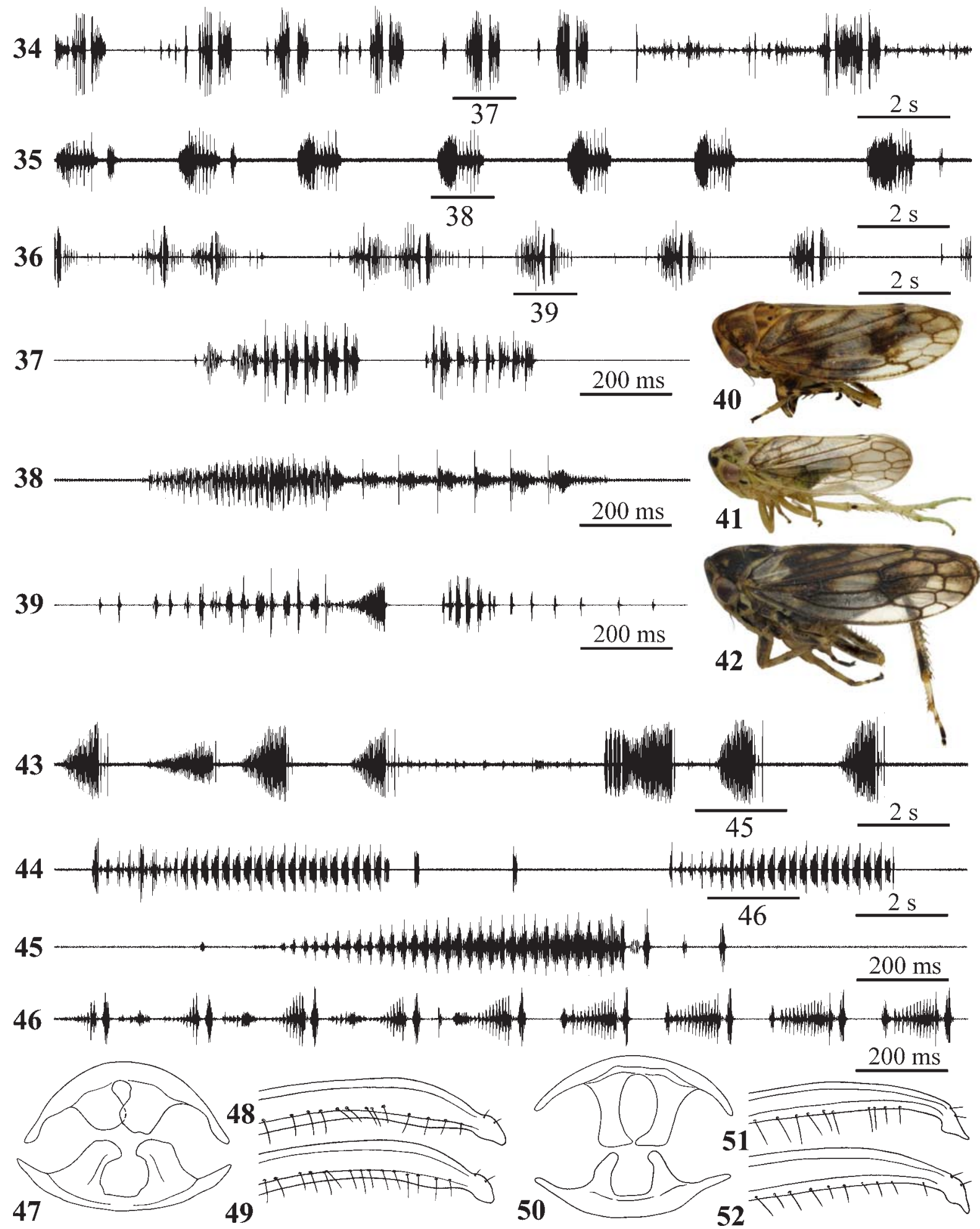

Figs 34-52. Macropsis spp.: M. mulsanti - 34, 37, 40; M. emeljanovi-35, 38, 41; M. pictipes - 36, 39, 42; M. elaeagni-43, 45, 47-49; M. elaeagnicola - 44, 46, 50-52; 34-39, 43-46 - oscillograms of calling signals; 40-42 — general view of a body, lateral aspect; 47,50 - male $2^{\text {nd }}$ abdominal apodemes; 48-49, 51-52 — end of style. Faster oscillograms of the parts of signals indicated as "37-39" and "45-46" are given under the same numbers.

Рис. 34-52. Macropsis spp.: M. mulsanti - 34, 37, 40; M. emeljanovi - 35, 38, 41; M. pictipes - 36, 39, 42; M. elaeagni - 43, 45, 47-49; M. elaeagnicola - 44, 46, 50-52; 34-39, 43-46 - осциллограммы призывных сигналов самцов; 40-42 - общий вид сбоку; 47, 50 - аподемы II брюшного сегмента самца; 48-49, 51-52 — вершина стилуса. Фрагменты сигналов, помеченные цифрами “3739” и “45-46”, представлены при большей скорости развёртки на осциллограммах под такими же номерами. 
short syllables (Figs 29 and 31, middle part of the oscillogram).

\section{Macropsis spp. from the sea-buckthorn (Hippophae rhamnoides L.):}

strictly sympatric species different in signal pattern and external appearance, but indistinguishable in genitalia shape.

Macropsis mulsanti (Fieber, 1868), M. pictipes (Horvath, 1904), and M. emeljanovi Dubovsky, 1966 are three monophagous species dwelling on sea-buckthorn. Their ranges overlap only partially, but in many regions of Central Asia these species are strictly sympatric i.e. dwell on the same plant and breed at the same season. For instance, in Sary-Chelekskiy Nature Reserve, West Tien Shan Mts., on the Southern shore of Issyk-Kul Lake, and in certain other places I have found mature males of all three species in the same sweeping sample.

These species differ from each other in calling signal pattern (Figs 34-39) and in body size and coloration (Figs 40-42), but not in the shape of male genitalia [Tishechkin, 2002]. It can be supposed that this group evolved as a result of the range disjunction of some ancestral form. Such a scenario is quite probable because sea-buckthorn grows on stony riverbanks in Alps, Caucasus, Central Asia, and Siberia. It has disjunctive mountain range and is absent in the plains of Europe and in the plain steppes and deserts of Kazakhstan and Central Asia. Partial sympatry of three species in the mountains of Central Asia apparently is a secondary state resulting from their range extension.

\section{M. elaeagni Emeljanov, 1964 and M. elaeagnico- la Dubovsky, 1966:}

strictly sympatric species different in signal pattern and genitalia shape, but indistinguishable in external appearance.

M. elaeagni and M. elaeagnicola dwell on the same host, Elaeagnus spp. The former species was introduced with the ornamental trees of Elaeagnus angustifolia L. far and wide outside its natural range, which is hardly possible to reconstruct now. Presently it occurs in Western Europe, European Russia (northwards as far as Moscow), Caucasus, Transcaucasia, Kazakhstan, and Central Asia. The range of the latter one is restricted to Ferghana Valley and surrounding mountains - Chatkal, Ferghana, Alay, and Turkestan Mtn. Ranges. In Central Asia I have collected the males of both species from the same tree not once, so they undoubtedly are strictly sympatric.

In contrast to three species from the sea-buckthorn, M. elaeagni and M. elaeagnicola are indistinguishable in external appearance except that M. elaeagnicola is slightly smaller. However, they differ distinctly in calling signal pattern (Figs 43, 45 and 44, 46) and have small, but constant differences in the shape of male 2nd abdominal apodemes (Figs 47 and 50) and style tips (Figs 48-49 and 51-52). Apparently, these two species also evolved as allopatric and overlapping of their ranges could result from the secondary range extension of M. elaeagni.

\section{Discussion}

From the above examples it can be seen that even within the same leafhopper genus divergence in different traits can occur in different species groups. However, certain regularities emerge in this process.

Strictly sympatric species dwelling on the same host can differ in external appearance, but not in genitalia shape (sea-buckthorn-dwelling species, Figs 34-42), or, on the contrary, in genitalia shape, but not in external appearance (two species from Elaeagnus, Figs 43-52). Anyway, such species always differ from each other in signal temporal pattern.

In $M$. ochotonaria and M. leporina dwelling on different hosts from the same plant community situation is similar. These two species are indistinguishable in morphology and coloration, but differ from each other in the signal pattern (Figs 29-33).

Incomplete sympatry in $M$. flavida, $M$. daurica, and M. multa as a consequence provides incomplete acoustic isolation. These species are indistinguishable in genitalia shape and sometimes also in coloration (Figs 18-22). Calling signals of all three ones differ in temporal pattern, but share certain common elements (Figs 23-28). Apparently, in this case host differences provide more or less sufficient reproductive isolation barrier. But this barrier is not strong enough, so some differences in signal patterns have been evolved.

In allopatric species, it does not matter whether they dwell on the same or different hosts. Also, such species can diverge in genitalia shape, as $M$. sahlbergi and $M$. chazarianus, or retain the similarity in this trait, as $M$. impura and $M$. flavida. Usually they differ in signal pattern, but this is not necessary, because reproductive isolation in this case is provided by range disjunction. For this reason signals of allopatric species sometimes are quite similar (Figs 10-17) or even identical (Figs 59). It is noteworthy, that in M. sahlbergi and M. chazarianus signal patterns remained identical in spite of considerable divergence in genitalia shape (Figs 1-4).

From these facts two conclusions can be drawn. First, this is the calling signal pattern, but not coloration or genitalia shape, which is a key element of SMRS in small Auchenorrhyncha. Second, host differences by no means always provide complete acoustic isolation for sympatric species even though they dwell on different species of trees or shrubs. Therefore, sympatric species always diverge in signal pattern, whereas for allopatric ones this is not necessary. Actually in nature there is a continuum between strict sympatry and full allopatry. For this reason in species inhabiting the same territory, signal pattern can be similar in more or less degree. In one case signals are quite different (sea-buckthorn- and Elaeagnus-dwelling species), but have certain common traits in another (M. ochotonaria and M. leporina; M. flavida, M. daurica and M. multa).

The divergence in coloration and/or morphological traits is a secondary event in relation to signal pattern divergence or range disjunction. Biological species are 
indistinguishable in these traits on the initial stage of divergence. Then differences in genitalia shape and/or coloration evolve, but various traits diverge independently of one another. As a result, some species differ in coloration, but not in genitalia shape, the others differ in genitalia shape, but not in coloration.

Evidently, the species groups under consideration evolved in different ways. Two species of Macropsidius and M. impura and M. flavida are typical and most simple examples of allopatric speciation. In these cases reproductive isolation resulted from range disjunction.

Species coexisting on the same host apparently evolve in two steps. At first the range of ancestral form splits into several parts and several biological species emerge. Then their ranges extend and these species become secondary sympatric. But when they met again after long separation, they have not recognized each other Because of the differences in signal patterns which have been evolved during the period of allopatry. This alternative is likely was realised in Elaeagnus- and seabuckthorn-dwelling species.

Evolving of the formally sympatric cryptic species (e.g. M. flavida, M. daurica, and M. multa) can be explained by both allopatric speciation followed by range extension and by sympatric speciation via host shift.

Dietrich [1999] suggested that in grass-feeding leafhoppers host shift and geographic isolation of populations from the same host are two main speciation mechanisms. Apparently, this concerns all other leafhoppers as well, and different speciation modes can be realized in different species groups within the same genus or subfamily.

ACKNOWLEDGEMENTS. I express my most sincere thanks to Nataliya Burlak (Sergiev Posad, Moscow Area) for invaluable help and support during our fieldwork in Astrakhan' Area, Kyrgyzstan, and in the Russian Far East. I am deeply grateful to Akynaly Dubanaev (Sary-Chelekskiy Biosphere Nature Reserve, Kyrgyzstan) for the help and hospitality during my visits to Sary-Chelekskiy Nature Reserve and to Dmitri Milko (Institute of Biology and Pedology, Bishkek, Kyrgyzstan) for organizing the expedition to Kyrgyzstan in 2014. I am greatly indebted to Prof. Kirill Makarov (Department of Zoology and Ecology, Moscow State Pedagogical University) for kind permission to make photographs of Macropsis specimens on his equipment.

The study was supported by Russian Foundation for Basic Research, grant No. 13-04-00046-a (field-work) and Russian Science Foundation, grant No. 14-50-00029 (data handling and manuscript preparation).

\section{References}

Claridge M.F. 1993. Speciation in insect herbivores - the role of acoustic signals in leafhoppers and planthoppers // Evolutionary Patterns and Processes. Linn. Soc. London. P.285-297.

Claridge M.F., de Vrijer P.W.F. 1994. Reproductive behaviour: the role of acoustic signals in species recognition and speciation // R.F. Denno, T.J. Perfect (eds.). Planthoppers: their ecology and management. Chapman and Hall. P.216-233.
Dietrich C.H. 1999. The role of grasslands in the diversification of leafhoppers (Homoptera: Cicadellidae): a phylogenetic perspective // C. Warwick (ed.). Proceedings of the Fifteenth North American Prairie Conference. Natural Areas Assoc., Bend, OR. P.44-48.

Drosopoulos S. 1993. Modes of speciation in leafhoppers, planthoppers and froghoppers: a review based on biosystematic data // S. Drosopoulos, P.V. Petrakis, M.F. Claridge, P.W.F. de Vrijer [Eds.]. Proceedings of the 8th Auchenorrhyncha Congress. Delphi, Greece, 9-13 Aug., 1993. P.106-107.

Drosopoulos S., Claridge M.F. (eds.). 2006. Insect sounds and communication. Physiology, behaviour, ecology and evolution. CRC Press, Taylor and Francis Group. Boca Raton, London, New York. 532 pp.

Gillham M.C., de Vrijer P.W.F. 1995. Patterns of variation in the acoustic calling signals of Chloriona planthoppers (Homoptera: Delphacidae) coexisting on the common reed Phragmites australis // Biol. J. Linnean Society. Vol.54. P.245-269.

Heller K.-G. 2006. Song evolution and speciation in bushcrickets. // Insect Sounds and Communication. Physiology, Behaviour, Ecology and Evolution. Eds.: S. Drosopoulos, M.F. Claridge. CRC Press, Taylor and Francis Group. Boca Raton, London, New York. P.137-152.

McNett G.D., Cocroft R.B. 2008. Host shifts favour vibrational signal divergence in Enchenopa binotata treehoppers // Behavioral Ecology. Vol.19. P.650-656.

Riede K. 1996. Diversity of sound-producing insects in a Bornean lowland rain forest // Tropical Rainforest Research. Kluwer Acad. Publ. Netherlands. P.77-84.

Rodríguez R.L., Sullivan L.E., Cocroft R.B. 2004. Vibrational communication and reproductive isolation in the Enchenopa binotata species complex of treehoppers (Hemiptera: Membracidae) // Evolution. Vol.58. No.3. P.571-578.

Sueur J. 2002. Cicada acoustic communication: potential sound partitioning in a multispecies community from Mexico (Hemiptera: Cicadomorpha: Cicadidae) // Biol. J. Linn. Soc. Vol.75. P.379-394.

Tishechkin D.Yu. 1999. Review of the species of the genus Macropsis Lewis, 1834 (Homoptera: Cicadellidae: Macropsinae) from the Russian Far East and adjacent territories of Transbaikalia // Russian Entomological Journal. Vol.8. No.2. P.73-113.

Tishechkin D.Yu. 2002. Review of the species of the genus Macropsis Lewis, 1834 (Homoptera, Cicadellidae, Macropsinae) from European Russia and adjacent territories // Russian Entomological Journal. Vol.11. No.2. P.123-184.

Tishechkin D.Yu. 2003. [Review of the species of the genus Scleroracus (Homoptera: Cicadellidae) from the territory of Russia] // Zoologicheskiy Zhurnal. Vol.82. No.12. P.1434-1444 [in Russian, with English summary]. English translation: "Entomological Review". 2003. Vol.83. No.6. P.740-750.

Tishechkin D.Yu. 2005. [A contribution to the taxonomy of Gargara genistae (Homoptera, Membracidae) and related species from Russia and adjacent territories] // Zoologicheskiy Zhurnal. Vol.84. No.2. P.172-180 [in Russian, with English summary]. English translation: "Entomological Review". 2005. Vol.85. No.1. P.12-20.

Tishechkin D.Yu. 2006. Leafhoppers of the genus Macropsidius (Homoptera: Cicadellidae: Macropsinae) in European Russia // Zoologicheskiy Zhurnal. Vol.85. No.4. P.470-478 [in Russian, with English summary]. English translation: "Entomological Review". 2006. Vol.86. No.2. P. 230-239

Tishechkin D.Yu. 2009. On the taxonomic status of Laburrus confusus Vilbaste, 1980 (Homoptera: Cicadellidae: Deltocephalinae) // Russian Entomological Journal. Vol.18. No.2. P.81-86.

Tishechkin D.Yu. 2010. On the variability of the temporal pattern of vibrational calling signals in leafhoppers (Homoptera: Cicadellidae)// Russian Entomological Journal. Vol.19. No.1. P. 31-40.

Tishechkin D.Yu. 2011a. Calling signals in sympatric species of the far-eastern Aphrophora (Homoptera: Auchenorrhyncha: Aphrophoridae): regularities of communication channel segregation // Russian Entomological Journal. Vol.20. No.1. P.57-64. 
Tishechkin D.Yu. 2011b. Do different species of grass-dwelling small Auchenorrhyncha (Homoptera) have private vibrationa communication channels? // Russian Entomological Journal. Vol.20. No.2. P.135-139.

Tishechkin D.Yu. 2013. Taxonomic study of Central Asian species of the genus Macropsis Lewis, 1836 (Homoptera: Auchenorrhyncha: Cicadellidae: Macropsinae). I: Redescriptions of willow-dwelling species from West Tien Shan Mountains // Zootaxa. Vol.3722. No.4. P.581-595.
Tishechkin D.Yu., Bukhvalova M.A. 2010. Acoustic communication in grasshopper communities (Orthoptera: Acrididae: Gomphocerinae): segregation of acoustic niches // Russian Entomological Journal. Vol.18 (for 2009). No.3. P.165-188.

Tishechkin D.Yu., Burlak N.A. 2013. Pure-tone vibrational signals in small Auchenorrhyncha // Zoologicheskiy Zhurnal. Vol.92. No.3. P.278-299. [in Russian with English summary]. English translation: "Entomological Review". 2013. Vol.93. No.9. P.1085-1106. 